\title{
The Sonnets of Seamus Heaney in Spanish ${ }^{1}$
}

\author{
Robert J. Miles \\ The School of Languages, Linguistics and Cultures \\ The University of Hull, UK
}

Received: 22-02-2016

Accepted: 28-03-2016

Published: 01-04-2016

doi:10.7575/aiac.ijclts.v.4n.2p.58

URL: http://dx.doi.org/10.7575/aiac.ijclts.v.4n.2p.58

\begin{abstract}
This paper seeks to offer a more nuanced and further-reaching exploration of the translation of all of Seamus Heaney's sonnets into a Spanish 'collected', lead by the Mexican poet Pura López-Colomé. Taking in critical thinking oncreativity and the 'post-colonial' sonnet as well as Heaney's and López-Colomé's own views and metaphorics relating to literary translation, this paper asks not only what Sonetos brings to the originals, but what they bring also to poetry and translation. The paper argues that Sonetos offers a distinct insight into questions of semantic faithfulness and the translator's visibility, but also that whilst we must eschew metaphysical or essentialist language in analysis, the project of Sonetoshas alsobeen to communicate not just original poetry's, but also translation'squalitiesas a strategyof (secular) revelation.
\end{abstract}

Keywords: Translation; Versioning, Sonnet, Poetry, Mexico, Seamus Heaney; Pura López Colomé, Creativity

\section{Introduction}

Perimeter is not meaning, but it changes meaning,

As wit increases distance, so compassion erodes it.

Jane Hirshfield ${ }^{2}$

There was always something especially trans about poetry. Considering it one of the most resistant and most intensively reflexive aspects of human communication, Octavio Paz famously asserted: 'No text can be completely original because language itself in its very essence is already a translation - first from the nonverbal world, and then, because each sign and each phrase is a translation of another sign, another phrase." He added: "The greatest pessimism about the feasibility of translation has been concentrated on poetry." Paz described a consensus that the denotative translation is possible, whereas the connotative ("woven of echoes, reflections") is impossible (trans. by Irene del Corral, q.v. Paz 1992: 154-155). ${ }^{3}$ A good example of this paradox, of poetry's apparently simultaneous translational insistence and resistance, can be found in poet-translator Pura López Colomé's collection and translation of the sonnets of Seamus Heaney in Sonetos (2008).

The task of tackling a traditional verse form, such as the sonnet would seem only to involve further parameters when rendering the connotative or approximating to the ever-evanescent original for a sense of the voice or author 'behind' the source poems. Heaney commented: "I think taking liberties is usually a problem. [...] I think that verse -whether it is ten thousand years old or ten years old - verse sets out to be a thing, a set-up in language. It sets itself up in words. It's made" (Heaney and Hass 2000: 30). Exploring Sonetos, this paper will firstly provide some discussion of this madeness and translation in relation to the creative process and the implications of concentrating on a particular form for both Heaney and López Colomé in very difference contexts. This paper will go on to consider how a virtue is made of a certain visibility, the meticulously crafted but simultaneously dialogical unfinishedness of Heaney's sonnets, and how these 'colonial' cohabitations are neither exactly wholly 'faithful', nor entirely free and 'versioned' renditions of Heaney's originals.

\section{Reader/Poet/Translator and Reader-Poet-Translator}

Working in just one language, reading or writing poetry is about carrying over, a transferral and - if it is any good - a movement of the bones. ${ }^{4}$ In creating poetry, there will still always be mediation after any initial inspiration or catalyst, after, what Seamus Heaney describes as that "first stirring of the mind round a word or an image or a memory" (Broadridge 1977: 48). There is nothing literal to work from. The poet has to capitalise on an initial impetus, then unravel, unpick, reform and adjust the thing perhaps only fleetingly overheard in themselves. Poets may 'transpose' another's words or some caught fragment into a meaningful (or amorphous, tantalizing, provocative, but essentially resonant) structure, inflecting and guiding it as it shapes up. If we define text here as any structure of meaning, the poet may even have to resist text, to oversee, rather, a perceivable event: something happening in the texture of the language itself, aiming for something always transpiring. The results may be surprisingly amusing, oblique, uncanny, or unnerving. Even if it is, as Auden asserts, only a rhythm that comes first, an evanescent (im)pulse, urge and urgency, the successful poet effectively transduces this as new verbal energy. ${ }^{5}$ As the erstwhile U.S. Poet Laureate, Stanley Kunitz (1905-2006) commented: 
The poem in the head is always perfect. Resistance starts when you try to convert it into language. Language itself is a kind of resistance to the pure flow of self. The solution is to become one's language. You cannot write a poem until you hit upon its rhythm. (Busa 1982)

The poet has to make sense of an image/make images into sense, get those best words in that right order, and communicate freshly by transfigurations, judiciously incorporating fresh or incongruous words and unconventional structures to exfoliate in the readers' imagination. Like all successful art, poetry is best always in transition. The poet may not always affect a stay against confusion exactly, but perhaps gesture or hint towards solutions, inducing intuition, even that unfathomable sense of restoration or revelation - that ineffable 'in the bones', psycho-corporeal effect in both poet and reader or audience.

Octavio Paz adds that "reading is translation within the same language. Criticism is a free version of the poem, [...] a transposition" (1992: 159). Any serious first-language reader's engagement with poetry is already akin to what the translator does with a text in another language. In first-language reception, the reader will have his or her own memories, knowledge, experience, socio-cultural frameworks, value systems and received illusions of permanence. The filtering or 'translational' act of reading or hearing a poem may not have to be laborious for a full, frozen or consensual final rendering; some entity, if only by its apparent ellipses, may materialise. A reader working between different languages will have these tasks too, but the translator is a reader with an agenda, despite any initial trust. The translator is going to arbitrate invariably and doto the text, as well as be taken with or by it, described as an act of aggression in Steiner's (2004: 193-198).

Translation has been called poetry's "parasitical in-law" (Cavanagh 2013: 236). The assumption is often that what the translator does is meddling and secondary — always chronologically of course — but also to many, always qualitatively too. Auden never clarifies why translation compared to other possible day jobs might not be so injurious for the poets (1973: 180). Arguably (particularly literary) translation's operations are germane to the poet's —as Heaney put itpsychological "haulage work" (McCarthy 2009). Auden perceives the inexorable trans nature of poetry, despite, or perhaps because of his claim and understanding that many start in a non-verbal way, in the mire of pre-articulation. Knowledge of foreign languages is perhaps not only for the bits and pieces of the language, but for the generative experience and appreciation of crypto-linguistic liminality and otherness.

For the non-entirely bilingual reader/poet, things are triply in other words already. For the purposeful translator/poet they are so only initially, but the unknotting might well also serve to reinforce their own expressive range, which may well feed back into their own work, or remain as part of the newly translated work. It could be the case that the translator - like the poet in the original language - whilst 'making sense' of the original has to resist actually making sense in the translation, understanding that in the cracks there is light. The poem's particularity may include its sociopolitical, regional or ethnic distinctiveness: texts may be foreignised or domesticated and in some way 'brought home' to paraphrase Schleiermacher's much-revisited terms (2004: 55-56).

When one considers the already polemical matter of 'voice' in poetry, the question of the transferral or surrogate agency in translation is even more fraught. Even factoring in the device of an obvious narrator or personification in an untranslated original poem, just who is heard and who is speaking the poem is a perennial question. Allen and Bernofsky note that the translator also becomes part of the stories he or she tells, although translation involves "guises and masks", and that "[t]o perceive the translator as endowed with agency, intent, skill, and creativity is to destabilize the foundations of the way we read [...], to see two figures where our training as readers, our literary upbringing, has accustomed us to seeing only the author" (2013: xix). While there always will be a removal from the perceived source, from some imagined matrix of the work of art, at the most superficial level, one might expect (and some have argued for this as a hallmark of quality translation), there will be very little or no sense of this removal. There will be no feeling of disjunction or the shock of disconnection except in the sense of a shock of re-perception, or some savouring of a cultural distinctiveness and specificity. We like to sense something has been subtly explained, rearticulated or served back to us as memorably meaningfully and/or emotively as if in the respective original language.

As noted from a different perspective above, sophisticated readers of translations are also open to the challenge; perhaps less of Steiner"s "epiphenomenal" or "contingent" difficulty, but more his "tactical" or "ontological" difficulties (1978: 18-47). Such readers might like to feel that any ambiguity, any provocative mystery was actually part of the original; that it was there for the poet and to all intuitive readers in the original language. On any level, readers want to experience that immaculate mix of means and message, and if not exactly "consecrated", as Heaney describes the serious poet (McCarthy 2009), the translator must at least be a fellow traveller. Peter Cole notes wryly: "There's negative capability and there's negative capability" (2013: 4). Monolingual creative writing and critical-historical teachers of poetic literature also know much can be understood, and much simply disintegrated in transferral. Certainly there are shipwreck translations. Katharina Reiss (2004: 174) points out the omni-metaphor of seafaring in translation studies, which Heaney extends:

[F]rom the point of view of the writer, words in a poem need what the Polish poet Anna Swir once called "the equivalent of a biological right to life". The erotics of composition are essential to the process, some prereflective excitation and orientation, some sense that your own little verse-craft can dock safe and sound at the big quay of the language. And this is as true for translators as it is for poets attempting original work. (2000: xxvi) 
Heaney's translators - such as Imreh András (Hungary), Jerzy Jarniewicz (Poland), Grigory Kruzhkov (Russia) and Francesca Romana Paci (Italy) - know thissince they are, or have closely collaborated with, other experienced poets There is almost no discussion of Heaney in translation in O'Driscoll's far-reaching Stepping Stones (2009), but elsewhere on of his work in other languages Heaney has been, by turns, gracious, honest, generous, intrigued or fascinated and sometimes very amusing. He felt, for example, that French "flows upward" whereas his original voice was one that "goes to the floor". To Heaney, translation could be perfidious: "Traduttore traditore [...] I simply do not know what would happen to these poems in Japanese or Chinese. [...] You can translate shapes, wisdom, and intonation. It is better to translate that not to translate, obviously" (McCarthy 2009).

Heaney re-poses fundamental questions: does the reader of a translation always cede the original? Can a translation of a poem be a new and genuine occurrence in the language? Revisiting these, a recent editorial introduction by Fiona Sampson for Poem magazine - laudably advocating a "new internationalism"- outlines some of the troublesome aspects of poetry translated and some particularly Anglophone preconceptions and prejudices. The piece concludes implicitly invoking Venuti (q.v. 2008), where Sampson adds: "They [translators] can be said to have succeeded best when they most disappear. The new internationalism relies, as all good literary practice does, on this kind of service". ${ }^{6}$ Sampson maintains the aim is to "return to the poems themselves", which must "come clear through the seethe of language" (Sampson 2013: 4). Should all translators disappear?

\section{Pura López Colomé and the Sonnet/Soneto}

An interesting case study and comparator in matters of agency, visibility and voice, versioning and translingual viability, but most intriguingly also transcultural, even transcendent, value - because of the translator's selection of a particular form and its presentation - can be found in Heaney translated into Spanish. With a proven track record in the successful and critically well-received translation of writers of the calibre and reputation of Samuel Beckett, William Carlos Williams, Gertrude Stein, Robert Hass, Robert Creeley, H. D. and others, the prolific and multi-award winning Mexican poet Pura López Colomé would be an obvious choice of poet-translator to be most closely involved with sharing Seamus Heaney with the Hispanic world. This said, a look at her poetry initially suggests such a relationship to be a very unusual one. There are shared approaches and output between López Colomé and Heaney in terms of tone, temperament and subject matter in their original work, but the former is also noted for her condensation, layering and hermeticism, her near "ontological" inscrutability even, where Heaney may be figurative or symbolic but still effectively direct, more colloquial or vernacular (Steiner 1978). Of course, poets do not have to be alike formally to translate each other, but the difference here is quite marked.

In a review of Watchword (2012), translated by Forrest Gander from the original Santo y seña (2007), Joseph Hutchison likens López Colomé's work to Montale, César Vallejo and Paul Celan as well as the oft-mentioned Emily Dickinson - a well known and acknowledged deep impact in López Colomé's formation, as poems such as 'Eco' attest (2012: 2427; 152), along with other notably largely Anglophone influences such as Dickens, Whitman and Yeats. López Colomé might also be compared to contemporaries such as Louise Glück, perhaps the flash insights and musings of Samuel Menashe, or the accumulative and compacted impressionism of Pauline Staineror Jane Hirshfield, and other key writers of spare, precise, powerful, though less straightforwardly narrative poetry. Hutchison comments on López Colomé's sensitivity, her engagement with language that "saves it from marginality" and obscurity, but, moreover, "forces her to abandon the linear aspects of poetry — narrative and argument of the sort we find in sonnets" (2013).

So, doubly unexpected might be the particular collection that is the focus of this paper: Pura López Colomé's translation of Seamus Heaney's sixty-one collected sonnets in the bilingual Sonetos. The collection has a limited distribution in the Anglophone world, which seems at first logical and inevitable, but in the context of translation and reinvigorating extant equivalent poetic forms across cultures seems a missed opportunity for those able to hear and comprehend even quite limited Spanish. The connection between Heaney and López Colomé was also deep and longstanding. She first encountered his work almost as it was being published in the 1960s, read to her by an Irish nun at her school in the U.S.A. The sensation of coming back to his work at the end of the 1970s she compares to "las primeras campanadas del alba en una aldea silenciosa" ["like church bells at dawn in a silent village"] (2013b). ${ }^{7}$ Beginning with Station Island (1984) [Isla de las estaciones], and with continual sense of destiny and compulsion (2013a), López Colomé went on to translate further Heaney collections: Seeing Things (1991) [Viendo visiones]; The Spirit Level (1996) [El nivel]; The Light of the Leaves (with artist Jan Hendrix) (1999), [La luz de las hojas]; and Human Chain (2011) [Cadena humana]. Fifteen of the translations for Sonetos are taken from these collections.

Extra prose renditions, which are not cribs or simply literal versions, are included in Sonetos with each original. As lead translator, López Colomé also credits the Chilean poet Luis Roberto Vera. On many occasions, including, at the launch of the book at the Facultad de Filosofía y Letras at the Universidad Nacional Autónoma de México, López Colomé insists she could not have done the work without him. Although some of these had already been worked into Spanish as part of the translation of previous Heaney collections, the general understanding is that Vera worked most closely on these prose companion pieces to each formally 'sonnetized' rendition in Sonetos (Montaño Garfias 2009).

In conversation with Robert Hass, Heaney emphasises rhyme as part of the sonnet's "movement" and "gear system". In the stricter soneto form López Colomé uses rhyme - unlike some French translations of his sonnets that Heaney considered problematic (Heaney and Hass 2000: 13). López Colomé recognises the form as a vigorous mechanism, and contends it does not have to be as strict as imagined. She notes that Heaney "tomaba ciertas libertades en cuanto a las esquemas de sus rimas, nos sentimos autorizados a echar mano de una cierta heterodoxia" [took certain liberties when it came to the rhyme schemes and felt permitted to be somewhat heterodox too]. She is clear that the Spanish incarnation 
is no more rigido than its English equivalent despite preconceptions (Heaney 2008: 15; 16).Like Heaney's original sonnets in English, her translations of each sufficiently conform to and also slightly stretch and test the parameters of the practice very much alive in the Hispanic tradition since the introduction of hendeca syllabics by Garcilaso de la Vega (and the model of the Italian octave followed by the Rima Alterata of the Italian sestet) in the $16^{\text {th }}$ century. Colomé adopts, adapts and reinvigorates what was polished by writers like Luis de Góngora, Francisco de Quevedo with the now conventional two four-line, two three-line stanzas. The soneto was to some extent associated with a tradition or stereotype of distinctly masculine erudition or muscular culteranismo, the proving of oneself as a writer by the mastery of form, despite Sor Juana Inés de la Cruz's extraordinary contribution — something addressed by Octavio Paz among others (1995). Using her own vernacular and progressive subject matter, the $17^{\text {th }}$ century Mexican genius Sor Juana made the form all her own. Like the Anglophone (primarily Shakespearean) model, what we have in Sonetos is largely what the collective Hispanic 'ear' has picked out, privileged and enshrined over time - despite a complex intercontinental evolution of which López Colomé is well aware.

\section{Homing the Sonnet}

Upon publication, Irish Pages sampled Sonetos, and the editor noted that the reader might "wonder why no solo edition of Heaney's Sonnets has ever appeared in the Anglophone world"(Agee 2008: 123). The mere existence of Sonetos prompts a consideration of these sonnets' combined energy and significance. The question of form transferred as well as translated, in the literary-historical context, provides another perspective, but certain overemphases could be misleading. For Thomas O'Grady, Heaney's sonnets engendered an engagement with what he calls the sonnet's "moreBritish-than-the-British fixed form" (2000: 354). He contends that Heaney's "remarkable command of the sonnet form [...] at least early in his career represented an overtly post-colonial gesture" (O'Grady 2000: 352). Heaney's use of the sonnet becomes increasingly culturally freighted with his growing public prominence and the conception of his voice as, rightly or wrongly, collectivised. ${ }^{8}$ In Cultural Translation and Postcolonial Poetry, Ashok Bery suggests another aspect of this appropriation by Heaney, writing that his use of it mitigates some of the artistically detractive nostalgia for cultural tradition or stereotypes (which initially presupposes a cultural superiority). The clichés of an idealised, telluric, autochthonous poetry (and poet) are, to Bery, "countermanded by, amongst other things, a continuing engagement with English literary traditions as well as with European culture more broadly" (2007: 3).

Whilst O'Grady privileges the political dimension and what he considers Irish poetry's particular responsiveness to the British sonnet in a decolonising sub-tradition not really seen elsewhere (2000: 354), when writing sonnets, almost any poet is likely to be working within some post-colonial context or other, in some global literary discourse of perceived correctness, tradition and received form, influence, precedence and power. These only obliquely intersect in terms of any actual dominance and subjugation in the case of Sonetos. But it is not really a question of Irish, British, or even Anglo-American cultural or linguistic preponderance in Latin America, although we might speak of the reiterated and mutual peripheralities of 'Mexican-Spanish' and 'Irish-English' in Sonetos. There are individually redolent, sometimes uncanny inclusions. Some of these are particularly resonant on their own and would translate with facility in many (especially troubled) socio-political contexts. Even in a Heaney sonnet like 'Strange Fruit' Bery argues we find the "various dislocations and in-between positions which connect the bog poems with the notion of translation" itself. Bery adds that in such cases, the translator is either nowhere or multi-located, or becomes culturally "amphibious" (2007: 120-121). By collecting and translating the sonnets exclusively López Colomé foregrounds Heaney in the context of controlling or colonial cultures (Heaney 2002: 364-382), and we might invoke his idea of the "through-other", a concept he applies particularly to his own condition as an Irish poet described as British (2002: 368) and to others" sense of themselves as positively multicultural, productively multi-located, rather than unclassifiable and, thus, lost -a "comfortable state of untidiness" as Bery summarises (quoting from Terence Dolan, 1998: 271). Bery also notes that "the time of through-otherness is a time of mixing" (2007: 4).

Heaney moved between Shakespearean schemes, between the abab-cdcd rhymed quatrains in the opening octet of the British model, and sometimes ends with the efefef of the Petrarchan/Italian closing sestet. He could, of course, often be freer than that, but he always provides that essential and defining turn in the piece, as does López Colomé, although her structures look quite different. She is slightly more formal sounding, but by no means mannered. Overall, the sense is one of exquisite balance and interplay. Recently voted Ireland's favourite poem of the last 100 years, III from 'Clearances' in the same sonnet sequence, The Haw Lantern(1987), 'When all the others were away at Mass', provides a good example of how well the 'sonnetized' and prose accompaniment work side-by-side. Heaney considered the Spanish language more intrinsically "rhetorical", baroque perhaps (McCarthy 2009), yet López Colomé and Vera convey the meditative, prayer-like tone of this excerpt, whilst still communicating the ambiguity in the imagery of the shared air, but also the ambivalence, the push-pull of being "all hers" ("todo suyo"), with the "dipping knives" ("el vaho y las cuchillas"), the overwhelming sense of emotion only just in check. We could comment further on the success at the level of lexical choice, subtle meter, equivalent slant or full rhymes and such rhythmic control of the long, almost breathless utterance.

Another example might be the translations of Heaney's VII from 'Glanmore Sonnets', where Heaney's very loose scheme and the tricky cultural specificities and resonance of the shipping news, the obvious alterity (but not quite exoticism) of place names perhaps inspires a certain tightening up in López Colomé's Spanish (Heaney 2008: 64-65). The prose offering acts as a good foil in these moments, but López Colomé's awareness and extraordinary skill is foregrounded at other times when, for example, the subject of the poem is superficially the use and abuse of terms themselves, but more profoundly also the place and power of words to define, unite or separate. In the affecting number 
IV of 'Clearances', when colloquialisms and repressed knowledge of institutionally-enshrined correct speech and the frowned-upon error become the point of contention between mother and son, López Colomé musters a Mexican street phrasing with an equally bitter-sweet, tragi-comic and unforced effect: "I'd naw and aye / And decently relapse into the wrong / Grammar which kept us allied and at bay.” becomes —'Náaa, pa'qué pronunciaba, / gramática incorrecta, con decencia, / nuestro aislamiento y nuestra propia alianza." (Heaney 2008: 106-107). López Colomé may be channelling the intensity of an inverse experience of growing up: "[I]n our house, any grammatical inaccuracy, even a small one or a peculiar usage, was considered unforgiveable" (2012: 49).

\section{Sonnets Beyond Themselves}

Let us not pretend: some of this facility is due to the nature of Heaney's work. For the most part, despite his innovations, Heaney is not oblique or abstract. There is an appreciable narrative aspect to his output with universal themes, which would travel well regardless. As noted above, there is also a malleability — which one might consider either help or hindrance - to his sonnets, which López Colomé says is reflected in the portmanteau nature of Sonetos. Along with the entire cabinet of curiosities that would be an analysis of the translators' work line-by-line, what also intrigues is the cabinet itself; the simple decision to collect only sonnets, and then offer two renditions each alongside Heaney's original. López Colomé writes:

Con las dobles versiones de los sonetos de Heaney, por nuestra parte, hemos pretendido, exclusivamente, poner de manifiesto que la forma latina del soneto, en su modalidad más libre y menos ortodoxa, le hace espejo a la forma sajona del mismo que el autor maneja, agregándole la diferencia de la acentuación. De este modo nos hemos hecho las ilusiones de que la traducción es posible, siempre y cuando la esencia artística se respete. (Heaney 2008: 17)

[With our double versions of Heaney's sonnets, we have tried particularly to highlight that the Latinate sonnet, in its freer and less orthodox form, can mirror the English one articulated by the author, incorporating the tonal differences too. In this way, we have dared to hope that translation is possible wherever one respects the artistic essence.]

Irene María Artigas Albarelli's insightful review of Sonetos calls our attention to - but, tantalisingly, does not really develop - an interpretation of an essential or "ritual" aspect to these translations, whilst also pointing out their multiplicity. Combination, placement and overall shape have become as suggestive and important as individual lexical selections in the bigger project figured as a kind of art object. ${ }^{9}$ Sonetos permits or even forces us to "establecer relaciones no sólo entre los poemas de una secuencia, sino entre las secuencias mismas y con los otros poemas, entre el español y el inglés, entre la versión libre y la rimada" (2009 308)[establish connections not only between poems in a sequence, but also the sequences themselves, and with other poems, between Spanish and English, between the free and rhymed versions]. She guides the reader to consider that the"diferencias entre las versiones no debe conducirnos necesariamente a preferir una de la formas a la otra, sino a recordarnos que nos encontramos ante un trabajo que es una y muchas secuencias, y que se asume como una serie"(2009: 309)[differences between the versions, should not necessarily lead us to prefer one form over another, but remind that we are faced with a work that is one and many sequences, which we take to be one series].

Artigas Albarelli considers that the sonnet seems always to "salirse de sí mismo" ["get beyond itself"], and these translations are no exception (2009: 309). Indeed, the translators foreground this capacity and López Colomé and Vera's design is appropriate but also in keeping with an entire unspoken philosophy of the on-going nature of the translational endeavour, not as something with no satisfactory conclusion in negative terms, but as something intrinsic to poetry - even in one language. Despite even López Colomé's suggestion that the readers can choose between them if they are presented this way (Heaney 2008: 15; Montaño Garfias 2009), the most effective translation or spectral 'version' is sometimes perhaps somewhere between the two renditions.

One reviewer of Sonetos does begin to gesture more towards this kind of reading. Daniel Saldaña París writes that between both translations:

se construye un equilibrio, un punto medio de literalidad y rima que se aproxima a la recreación del impulso original del poema. Este poema intermedio, imaginario, exige por lo demás una actitud activa, e incluso creativa, del lector, que debe deducir su forma a partir de las dos versiones ofrecidas. (2004: 84)

[a balance can be struck, a meaningmid-point, somewhere close to a recreation of the original impulse of the poem. This imaginary intermediate poem requires an active, even creative stance from the reader who must make out its form from the two versions on offer.]

Saldaña París suggests that the translators have taken a leaf from Heaney's writing on translation (from the selected essays also translated by López Colomé, q.v. Heaney 2006). In Sonetos, the prose rendering and the formal sonnet in traditional form still represent departures from preconceived norms individually, and especially so when paired: a perpetual interchange would be precluded by the possibility of complete semantic dissipation of the original 'fixed' sonnet, but the creative possibilities of such interchange are still implied. Rendering Heaney"s "shapes, wisdom, intonation" (McCarthy 2009), his own sensitivity to being both home and away is achieved also on another level. The 
'stricter' sonnets have their otherness, their formal 'educated' distancing yet also the 'movement' of their more subliminally-expected rhymes, rhythms and memorability. The prose is initially familiar, more apparently vernacular, yet it is strongly and purposely tuned, rhythmic and stylised, as López Colomé and Vera are at pains to point out (2008: 16).

\section{Liminality, Adumbration and 'Transcendence'}

Whilst noting how translation is an analogue for the (post)colonial experience, particularly in Latin America, Susan Bassnett also describes translation as an act of faith, cannibalism even, but also one in which is "seen in terms of physical metaphors that stress both the creativity and the independence of the translator" (2005: 5-6). Both Heaney and Paz, for example, employ a metaphorics of the fixed and the fluid (Heaney 2000: xxii). Paz describes a dichotomy and parallel: there is fluidity and open-endedness in the poet's experience, but the translator has foreknowledge of a prefixity of things (1992: 159) — something accentuated when translating received, traditional forms such as the sonnet. Paz posits the initial fluidity for the originator or conduit of a poem from the continuum of the unarticulated: "immersed in the movement of language" forming "a verbal object made of irreplaceable and immovable characters." However: "The translator's starting point is not the language in movement that provides the poets raw material but the fixed language of the poem. A language congealed yet living." Likewise, Heaney comments in interview that "the usual analogy for completing a piece of writing, [is] saying that it is like a piece of carpentry. For all the satisfaction that the cabinetmaker gets from the wood and all that, he probably feels, it's not really mine when I finish it, it belongs to it, to the wood" (Heaney and Hass 2000: 30).

When asked mischievously by Robert Hass if Heaney had an overriding theory of translation, Heaney responds with another metaphor:

Now, a very good motive for translation is the Raid. You go in — it is the Lowell method — and you raid Italian, you raid German, you raid Greek, and you end up with booty that you call Imitations.

Then there is the Settlement approach: you enter an oeuvre, colonize it, take it over - but you stay with it, and you change it and it changes you a little bit. (Heaney and Hass 2000: 1)

Heaney's thoughts on its use are entirely consonant with the business of translator-poet-readers such as López Colomé and Vera, working with inherited, contiguously evolving forms in polyphonic, postcolonial contexts of confluent and harmonised, or still dissonant and disembodied voices, but not by attempting to 'capture' or equal some original 'impulse' or 'essence' (even in López Colomé's explication) but where the translator is also the comfortably untidy "through-other" (Heaney 2002: 368), aiming towards a kind of eventual shared breath, an aspiration to a sense of shared inspiration or translational convivencia ('a living-togetherness').

Translators, poets and critics can slip into that mercurial lexis of the essentialising/ pre-constructivist, in search of the 'core', the 'kernel', 'heart' or 'spirit' of the original. The tenor of López Colomé's welcome introduction to Sonetos is not just allied to an unembarrassed sense of poetic vocation (evident across her prose), but is also a function of the attempt to describe the frustration and elation of writing, reading and rendering as contiguously creative acts. Where O'Grady ends his short study of Heaney's sonnets with 'At the Wellhead' — a 'parable on art itself' (O'Grady 2000: 364) - and the tale of blind Rosie Keenan, so López Colomé begins Sonetos with the same, using a line ("I can see the sky at the bottom of it now") to summarise "lo que en efecto ocurre gracias a la poesía" ["what actually happens thanks to poetry"], referring to the "verdadera alquimia verbal, el poder concedido — no adquirido - del arúspice y del mago" ["the real verbal alchemy, the power granted — not gained — by the haruspex and the magician"] (Heaney 2008: 9-10). López Colomé refers to Heaney's "visionary power" and poetics as one of continual quasi-mystical transformation and creation.

Heaney considers the very capable López Colomé 'full of negative capability' and that he had "benefited to the point of being blessed by having her as the one who cared for my work" (Agee 2008: 145). ${ }^{10}$ Curiously, López Colomé translates one volume's punning title Seeing Things — which holds four very challenging sonnets — as Viendo Visiones. Neil Corcoran analyses the original English as that "balance between scepticism and yearning [...] which raises the possibility of delusion in the same phrase in which it declares the possibility of revelation. The result is poetry of what we might call secular spirituality" (1998: 163). López Colomé's "visiones" in Spanish avoids the rather drab "cosas" (things), which might have been the more mundane alternative. Corcoran considers Seeing Things, and the sonnet 'The Journey Back' in particular, as some of Heaney's most poetically reflective work, invoking the origins of all such poetry: "the heartland of the ordinary" which is no longer a place but a "way' or "route' ("rumbo" and "vía") in López Colomé's translation. There is no overzealous catholicity or extra-mystical bent to her rendition, but she finds compensatory expression for what Corcoran considers "the quotidian [...] always prelude to transformation or translation." Corcoran contends that a "large number of the poems in Seeing Things define this process of translation itself" (1998: 165) — something not just not lost, but distinctly re-found in Sonetos.

If there is here some sense of that ritual and collective dimension to Sonetos as Artigas Albarelli put it enigmatically (2009: 308), perhaps there are shades of a shared communal enterprise, something aesthetically, even philosophically or para-spiritually restitutive because of the deliberate 'trans-ness' of the fixed-fluid. For all its apparent fixity in various traditions, the most traditionally realised of sonnets can actually become that most trans of poetic forms by a conscientious curation, as in Sonetos. The differences between the original, the Spanish prose and the poetic-formal versions in Sonetos are not foregrounded, nor smoothed over, but they adumbrate arguably a third field where the poem 
now exists. Extrapolating from Anthony Pym's understanding of the dialectics of translation, Bery offers a corrective to Schleiermacher's "strict binarism". Doubly reflexive works such as Sonetos are persuasive markers of an interstitial 'third-way' alternative to translations that are "only a movement inward towards the native culture or only a movement outwards towards the foreign culture." Bery contends that Schleiermacher excluded the "intercultural place where the translator stands, the middle ground of hybridity" (2007: 13). Perhaps Sonetos also embodies or reiterates Heaney's deeply considered restorative, even salvific "stance toward life" (Heaney 2002: 19). O'Grady noted this particularly in 'Requiem for the Croppies' (2000: 355), and more recently, John Dennison has traced the various revisions and evolutions in Heaney's ambivalent and complex conception of a moral and social, or even quasi-mystical or secularredemptive "total adequacy" of poetry. Dennison describes Heaney's subtle shifts from a language of transcendence to that of the fluid-interstitial: "our 'in-betweenness', this necessary state, a consequence of our situation between earthy origin and angelic potential. [...] Although now generally formulated in less metaphysical terms, Heaney's poetics remain replete with late humanist conviction" (2015: 196-197): a language whose metaphorics seem interchangeable with Heaney (and López Colomé) on translation.

For an idea of what Heaney calls this "domain of the 'eternally recurrent' [...] where the strains of 'no ending' and 'still' and 'more' echo and overflow above the brim of the usual" we can point to (a late, momentary metaphysical flourish in) his writing on the evolution of Wordsworth's 'The Solitary Reaper', based on Thomas Wilkinson's original prose. Heaney describes the eventual poem as a shift into "the eternal present of song-time". It is arguable Heaney's extra enjoyment of this is based on knowledge of that original prose, the uncredited 'trans-ness' of its shift into regulated poetic form. Heaney describes how Wilkinson's "exact words", his "notation becomes incantation in the poem". The sense of fixed and final destination is both intensified and assuaged for the reader because of the poet "translating' from the known original, which was not a poem (Thomson 2011: xi). Like Paz describing that "third poet", inspired through translation "in yet another language" (1992: 162), the sense of translation as a way to go on exploring or foster an imaginary of the infinite, is reiterated at the end of López Colomé's introduction to Sonetos where she quotes the wistful last lines of Larkin's 'High Windows'. Sonetos comes some way to expressing that "innermost relationship of languages to one another" as Walter Benjamin argued is the translator's task, (1996: 255). However the translators do not 'become' the language in Kunitz's problematically metaphysical terms (above, Busa 1982). Nor do they accede to some sphere of Benjamin's utopic "pure language" (1996),but their interactive nature speaks to both original poetry and translation's processual potential: their complementary and continual trans-ness - to be always becoming. Sonetosrepresents a kind of counter-intuitive authenticity despite its avowed reflexivity and potential 'exposure'. Poetic forms and versions in genuine conference represent at least an initial way in for those mentioned above, those triply removed from the poem who might not have command of the original poem, and certainly not of both languages in play. Although Fiona Sampson (above) is implicitly addressing the matter of translation into English as part of the "new internationalist" project, something like Sonetos might not quite sit so ideally invisible with regard to the assumed "service" of the translator. In terms of returning "to the poems themselves" as Sampson hoped, that depends on perspective and invokes a potentially labyrinthine epistemology. Sonetos as a projectis a worthy, multivalent object of study for anyone interested in collaborative and contiguous versions: transcontinental, transhistorical, trans-formal and transculturally co-authorial (not to mention also bi- or perhaps even transgendered), each part of Sonetos functions independently, but in its combinations it declares its new "biological right to life" (Heaney 2000: $x x v i$ ).

\section{Conclusion}

Translation and poetry are both strategies of purposefully accidental revelation. This paper argues that Heaney's sonnets ultimately 'ring true' in Sonetos because of the translators' salutary awareness not only of the inextricability of 'transcendental' art and inspiration from'mundane' craft or artifice, but also their positive interdependence. Momentarily, each Heaney sonnet in Sonetos, figured as one poem, becomes part of a dynamic totality of approximations. This paper foregrounds what might be initially clearer to bilingual readers, that this entire collection can be read as creatively meta-critical, that the compulsion to translate (like that of literary creation from scratch) is not only due to translation's potential to overcome the difference between languages (as in all poetry between cultures, ideas, memories and histories), but because it also paradoxically exposes those differences, as noted by Paz (1992: 154). In this case they also expose difference by focussing on one form often presumed to remain the same, but one that has long been in flux or a continual provocation to alter and rearrange: the well-travelled form of the sonnet. Simply to gather Heaney's sonnets in their original form has been significant, but arranged and translated as they are in Sonetos they engender a twisting helix of intra- and extra-textual implication and the impossibility of any final rendition as they abjure conclusiveness and point us back to an appreciation of the sense of the creative decisions and dilemmas in any original poem. At the simultaneously fraught and inspirational interstices of originality and reproduction, inspiration and imitation, Sonetos is a fitting homage to and generous sharing of Heaney's sonnets not in spite of its reflexivity, but because it dynamically and edifyingly embodies (as one inter visionary project) the worthwhile tensions, stresses and thus the successes of great original poetry.

\section{References}

Agee, Ch. (ed.). (2008). 'Heaney's Sonnets into Spanish'.Irish Pages ('In Other Words'), Vol. 5, No. 1 Language and Languages: Irish Pages Ltd, 123-146. 
Artigas A., Irene María. (2009). 'Reseña: Seamus Heaney, Sonetos', Anuario de Letras Modernas. Vol. 15, Mexico: Universidad Nacional Autónoma de México, 304-311.

Auden, W. H. (1973). 'The Poet and the City', in J. Scully (ed.) Modern Poets on Modern Poetry.London and Glasgow: Fontana, 173-193 (first published in The Dyer's Hand, 1962).

- (2000). 'from The Virgin and the Dynamo', in W. N. Herbert and Matthew Hollis(eds), Strong Words: Modern Poets on Modern Poetry. Newcastle upon Tyne: Bloodaxe Books, $67-71$ (first published 1962).

Bassnett, S. (2005). Translation Studies. London and New York, Routledge.

Benjamin, W. (1996).'The Task of the Translator', in Marcus Bullock and Michael W. Jennings(eds), Selected Writings: Volume 1 1913-1926. Cambridge, Massachusetts and London: The Belknap Press of Harvard University Press, 253-63.

Bery, A. (2007). Cultural Translation and Postcolonial Poetry. Basingstoke: Palgrave Macmillan.

Broadridge, E. (ed.)(1977). Seamus Heaney:Skoleradioen. Copenhagen: Danmarks Radio.

Busa, Ch. (1982). 'Stanley Kunitz: The Art of Poetry No. 29' (interview).The Paris Review, No. 83 (online 2014): http://www.theparisreview.org/interviews/3185/the-art-of-poetry-no-29-stanley-kunitz [accessed 1 March 2015].

Cavanagh, C. (2013). 'The Art of Losing: Polish Poetry and Translation', in Esther Allen and Susan Bernofsky (eds), In Translation: Translators on their Work and What it Means. New York: Columbia University Press, 234-246.

Cole, P. (2013). 'Making Sense in Translation: Towards an Ethics of the Art', in Esther Allen and Susan Bernofsky (eds), In Translation: Translators on their Work and What it Means. New York: Columbia University Press, 3-16.

Corcoran, N. (1998). The Poetry of Seamus Heaney: A Critical Study. London: Faber \& Faber.

Dennison, J. (2015). Seamus Heaney and the Adequacy of Poetry. Oxford, Oxford University Press.

Dolan, T. (1998). A Dictionary of Hiperno-English: The Irish Use of English. Dublin, Gill and Macmillan.

Esther, A. and Bernofsky, S. (2013). 'Introduction: A Culture of Translation', in Esther Allen, and Susan Bernofsky (eds), In Translation: Translators on their Work and What it Means. New York: Columbia University Press,xiii-xxiii.

Hall, J. (2002). 'Heaney's Requiem for the Croppies'.Explicator, Vol. 61, No. 1, 56-59.

Heaney, S. (2000). Beowulf: A New Verse Translation. London and New York: W. W. Norton \& Company.

— (2002). Finders Keepers: Selected Prose 1971-2001. London: Faber \& Faber.

- (2006). Al buen entendedor: ensayos escogidos (translated by Pura López Colomé). México, Fondo de Cultura Económica de España.

- (2008). Sonetos (translated by Pura López Colomé and Luis Roberto Vera with photographs by Alberto Darszon). Mexico D. F.: D. G. E. Equilibrista (all originals in English published London: Faber \& Faber).

Heaney, S. and Hass, R. (2000). Sounding Lines: The Art of Translating Poetry, Dorothy B. Townsend Center Occasional Papers (ed. by Christina M. Gillis). University of California, Berkley: Hunza Graphics.

Hirshfield, J. (2012). Come, Thief. Tarset: Bloodaxe Books.

Hutchison, J. (2013). 'A Hermetic Conversation: Watchword by Pura López Colomé', Cerise Press: A Journal of Literature, Arts and Culture (online). Summer, Vol. 5, No. 13: http://www.cerisepress.com/05/13/watchword-by-puralopez-colome [accessed 15 April 2014].

López Colomé, P. (2007). Santo y seña. Mexico D. F.: Fondo de Cultura Económica.

- (2007b). Mother Tongue: Selected Poems (translated by Lorna Shaughnessy). Galway: Arlen House.

- (2012). Watchword (translation of Santo y seña, 2007 op. cit., by Forrest Gander). Middletown Connecticut: Wesleyan University Press.

— (2013a). 'Retrato incompleto de Seamus Heaney', Nexos (online). 1st October, http://www.nexos.com.mx/?p=15516 [accessed 12 August 2014].

- (2013b). 'Náutico compás del universo: Seamus Heaney, 1939-2013', Letras Libres, October. México D. F. and Madrid: Editorial Vuelta, 103-104.

McCarthy, C. (director). (2009). Seamus Heaney: Out of the Marvellous (DVD). Icebox Films, RTÉ.

Maxwell, G. (2000). 'Strictures', in Herbert, W. N., and Matthew Hollis (eds), Strong Words: Modern Poets on Modern Poetry. Newcastle upon Tyne: Bloodaxe Books, 256-259.

Montaño Garfias, E. (2009). 'Traen a México la colección más completa de sonetos del Nobel Seamus Heaney'. La Jornada (online) http://www.jornada.unam.mx/2009/03/06/cultura/a05n1cul [accessed 25 March 2015].

O'Driscoll, D. (2009). Stepping Stones: Interviews with Seamus Heaney. London: Faber \& Faber.

O'Grady, Th. (2000). 'The Art of Heaney's Sonnets'. Dalhousie Review, No. 80, Autumn, 351-363.

Paz, O. (1971). 'Traduccíón: literatura $\gamma$ literalidad'. Barcelona: Tusquets Editor. 
- (1992). 'Translation, Literature and Letters' (translated by Irene del Corral), in John Schulte and Rainer Biguenet (eds), Theories of Translation: An Anthology of Essays from Dryden to Derrida. Chicago: University of Chicago Press.

- (1995). Sor Juana Inés de la Cruz o las trampas de la fe. México: Fondo de Cultura Económica.

Reiss, K. (2004). 'Type, Kind and Individuality of Text: Decision Making in Translation', in Lawrence Venuti (ed.) The Translation Studies Reader ( $2^{\text {nd }}$ edition). New York and London: Routledge, 168-179.

Saldaña París, D. (2009). 'Versar Irlanda: Sonetos, de Seamus Heaney’.Letras Libres, June, México D. F. and Madrid: Editorial Vuelta, 83-84.

Sampson, F. (ed). (2013).'Editorial', Poem. Vol. 1, No. 4, Winter 2013, London, University of Roehampton.

Schleiermacher, F. (2004). 'On the Different Methods of Translating' (trans Susan Bernofsky), in Lawrence Venuti (ed.) The Translation Studies Reader (2 ${ }^{\text {nd }}$ edition). New York and London: Routledge, 43-63.

Steiner, G. (1978). 'On Difficulty', in On Difficulty and Other Essays. Oxford: Oxford University Press, 19-47.

- (2004). 'The Hermeneutic Motion', in Lawrence Venuti (ed.) The Translation Studies Reader (2 ${ }^{\text {nd }}$ edition). New York and London: Routledge, 193-194.

Thomson, D. (2011). The People of the Sea (With an Introduction by Seamus Heaney). Edinburgh, Canongate.

Tóibín, C. (2014). 'Dictions and Discoveries'. PN Review, Vol. 41. No. 2, Manchester, Carcanet, 59-60.

Venuti, L. (2008). The Translator's Invisibility: A History of Translation (2 ${ }^{\text {nd }}$ edition). Abingdon, Oxford: Routledge.

\section{Notes:}

${ }^{1}$ A version of this paper was read at 'The Place for Poetry', organized and hosted by the Writers' Centre, Department of English and Comparative Literature, Goldsmiths, University of London (7th-8th May, 2015). My thanks to those who attended for useful feedback.

${ }^{2}$ From ‘Critique of Pure Reason' (Hirshfield 2012: 15).

${ }^{3}$ The original Spanish is in Paz (1971).

4 To permit a pun on 'translation' as the term for the movement of relics, particularly the bones of saints. Glyn Maxwell's asserts that poetry "is the language in thrall to the corporeal, to the pump and procession of the blood" (2000: 256). Colm Tóibín has it that the poem's "sound patterns and rhythmical system might be enough to satisfy some need within the poet's nervous system" to the extent that it "matters less what the poem says, or what it is about" (2014: 59).

${ }^{5}$ Auden is regularly cited as an exponent of rhythm in modern poetry and it is, for him, the marker of some liminal form and order emerging from the inchoate: "Rhythm is to time what symmetry is to space" (2000: 68).

${ }^{6}$ Allen and Bernofsky offer a clear overview of the increasingly accepted even necessary visibility of the translator (2013 xix-xx).

${ }^{7}$ Unless noted otherwise in this study, the translations from Spanish are mine.

${ }^{8}$ See also: Hall (2002) on Heaney's 'Requiem for the Croppies'.

${ }^{9}$ Sonetos also includes photography by the scientist, specialist in human reproduction (and husband of López Colomé), Alberto Darszon. The images are abstractions made from close-ups on, or magnifications of, found objects. The text on the back cover of Sonetos draws our attention to potential reading as well as 'seeing' or 'listening' strategies as the whole text as a discovered artifact:

Hay forma en el arte figurativo y en el arte abstracto, tanto así que uno puede llegar a ser reflejo o eco del otro. No de otra manera, la figura de dos cuartetos y dos tercetos resuena cual eco de imagines fotográficas abstractas, halladas en este mundo de manera natural.

[There is form in figurative and abstract art, to the extent that one can be a reflection or echo of the other. In this way, the form of two quatrains and two tercets chimes with the abstract photographic images drawn naturally from the world.]

${ }^{10}$ See also: Heaney and Hass (2000: 28). 